\title{
Fontanelle Closure Indicator
}

National Cancer Institute

\section{Source}

National Cancer Institute. Fontanelle Closure Indicator. NCI Thesaurus. Code C154909.

An indication as to whether the fontanelle is closed. 